\title{
A Comparative Study of Single Dose Dexamethasone versus Ondansetron for control of Post Operative Nausea and Vomiting after High-Risk Surgeries
}

\author{
Joginipally Ashwin ${ }^{1}$, Dr. Nikhil Mudgalkar² \\ ${ }^{1}$ Associate Professor, Department of Anesthesia, Prathima Institute of Medical Sciences, Nagnoor, Karimnagar. \\ ${ }^{2}$ Professor, Department of Anesthesia, Prathima Institute of Medical Sciences, Nagnoor, Karimnagar. \\ Corresponding Author : Dr. Joginipally Ashwin, Department of Anesthesia
}

\section{ABSTRACT}

Background: The occurrence of postoperative nausea and vomiting is generally associated with anesthesia and surgery. The problem is compounded in cases of high-risk surgeries where the incidence is quite high. The present study was designed to compare the efficacy of Dexamethasone and Ondansetron. Methods: This study was undertaken at the Prathima Institute of Medical Sciences, Naganoor, Karimnagar. In this randomized, open clinical trial, we studied 80 ASA grades I to $1 \mathrm{~V}$ patients of age group 20-60 years undergoing Laparoscopic Laparotomy, Major Gynecological surgeries, Renal, Shoulder and ENT surgeries under general anesthesia. The patients were randomly divided into two groups, Group I and Group II, each consisting of 80 patients. Group I received $4 \mathrm{mg}$ dexamethasone intravenous (IV) just after intubation and group II received $4 \mathrm{mg}$ Ondansetron intravenous (IV), just before extubation. Results: The most common age group was 50-59 years which had $n=45(28.1 \%)$ patients out of which group I was $n=24(15 \%)$ patients and $n=21(13.1 \%)$ patients. The next common age group was $20-29$ years out of which $n=23$ (14.4\%) and $n=18(11.2 \%)$. ondansetron group, early nausea is mild in $6.9 \%$, moderate in $3.8 \%$, and severe in $1.2 \%$ of patients. Whereas in the dexamethasone group early nausea is mild in $6.2 \%$, moderate in $4.4 \%$, severe in $1.9 \%$ of patients. In the ondansetron group, late nausea is mild in $9.4 \%$, moderate in $3.8 \%$, and severe in $0.6 \%$ of patients. Whereas in the dexamethasone group late nausea is mild in $7.5 \%$, moderate in $4.4 \%$, severe in $0.6 \%$ of patients. In the ondansetron group, early vomiting is mild in $5.0 \%$, moderate in $0.6 \%$, and severe in $0.6 \%$ of patients. Whereas in the dexamethasone group early vomiting is mild in $4.4 \%$, moderate in $1.2 \%$, severe in $0.6 \%$ of patients. Conclusion: dexamethasone given intravenously just after intubation and ondansetron given intravenously just before extubation are safe and have similar efficacy in postoperative nausea and vomiting after elective surgeries under general anesthesia having a high risk of PONV.

Keywords: Dexamethasone, Ondansetron, PNOV

\section{Introduction}

Some of the decisive events following surgery and anesthesia are pain, Nausea, and vomiting. At times nausea and vomiting may become more troublesome especially after minor or ambulatory surgical procedures resulting in delayed hospital discharge and increase the cost burden to the patients ${ }^{[1]}$. Because of these reasons the postoperative pain, nausea and vomiting management has received greater attention in the past two decades. Despite the availability of newer medications the incidence of nausea and vomiting still remains very high. It is found in the range of $20-30 \%$ of all cases of surgeries ${ }^{[2]}$. More than one and half-century ago John Snow described the phenomenon of nausea and vomiting ${ }^{[3]}$. His was the first extensive description of the phenomenon which was published in 1948, within 18 months of the introduction of anesthesia into Great Britain. He observed that vomiting was more likely to occur in patients who have taken food before the surgery. In most cases, the vomiting lasted only for a few minutes but in some, it continued for hours and even days. He suspected that movement shortly after operation might have triggered the vomiting. It has been suggested that PONV may result from causes other than anesthetics ${ }^{[4]}$. There are at least three kinds of vomiting, the first of which has been attributed to anesthetics such as ether, the second to reflex responses, and the last to opioids ${ }^{[4]}$. The subsequent investigation unfolded a spectrum of non-anesthetics factors in the pathogenesis of PONV. Persistence in nausea and vomiting can have serious medical consequences to the patient as well as financial implications in delayed discharge from the hospital. Now the number of acceptable surgical procedures has increased in the field of ambulatory anesthesia and the need to find more effective alternatives to the options available has become more urgent.

Dexamethasone was first reported to be an effective antiemetic agent in patients undergoing cancer chemotherapy in $1981^{[5]}$. Since then randomized, placebo-controlled studies have shown that dexamethasone and other steroids are significantly better than other agents (Metoclopramide, Prochlorperazine, Droperidol, Domperidone) in preventing 
nausea and vomiting associated with chemotherapy. A single dose of dexamethasone (4-8mg IV) is effective for PONV prophylaxis (but not treatment) particularly when it is combined with other anti-emetics. Ondansetron of the class of selective 5 hydroxytryptamine subtype $3(5 \mathrm{HT} 3)$ receptor antagonists which lack effects on cholinergic adrenergic, dopaminergic or histaminergic receptors ${ }^{[6]}$. Ondansetron is structurally related to serotonin. 5HT3 receptors are located both peripherally (Vagal nerve terminals) and centrally (Chemoreceptor trigger zone). The antiemetic property of Ondansetron may be mediated peripherally, centrally or both. Ondansetron has little effect on lower esophageal sphincter pressure, esophageal or gastric motility, or small bowel transit time ${ }^{[7]}$. The use of Ondansetron has now become extended to the management of PONV routinely. With this background, we in the present study tried to evaluate the efficacy of Dexamethasone versus Ondansetron for the prevention of PNOV in high-risk surgeries in our tertiary care hospital.

\section{Material and methods}

This study was undertaken at the Prathima Institute of Medical Sciences, Naganoor, Karimnagar. Institutional Ethical committee permission was obtained for the study. Written consent was obtained from all the participants of the study. The study consisted of 160 adult patients, posted for elective surgeries carrying a high risk for PONV. In this randomized, open clinical trial, we studied 80 ASA grades 1 to $1 \mathrm{~V}$ patients of age group 20-60 years undergoing Laparoscopic Laparotomy, Major Gynecological surgeries, Renal, Shoulder and ENT surgeries under general anesthesia. The patients were randomly divided into two groups, Group I and Group II, each consisting of 80 patients. Group I received $4 \mathrm{mg}$ dexamethasone intravenous (IV) just after intubation and group II received $4 \mathrm{mg}$ Ondansetron intravenous (IV), just before extubation. The preoperative visit was conducted on the previous day of surgery. A detailed history and present complaints were noted. General and systemic examination of the cardiovascular, respiratory and central nervous system was done by the primary investigator. Routine laboratory investigations like hemoglobin level, total count and differential count, routine urine, blood urea nitrogen, serum creatinine, bleeding and clotting time and ECG were

done. A thorough airway examination has been done. Patients were advised to remain nil orally after midnight and all of them received tablet diazepam 10mg orally in the night before surgery. Inj. Fentanyl and Inj. Glycopyrrolate was given $5 \mathrm{~min}$. before induction. Premedication was satisfactory. Regional anesthesia in the form of epidural anesthesia or peripheral blocks were

Performed whenever possible. General anesthesia with intermittent positive pressure ventilation was given to all patients. Preoperative blood pressure and pulse rate were recorded in operation theatre after connecting to the following monitors. Continuous electrocardiogram.

Sphygmomanometer, Pulse oximetry Intravenous cannulation with an $18 \mathrm{G}$ catheter was established. After 3 minutes of pre-oxygenation, anesthesia was induced with $2 \mathrm{mg} /$ $\mathrm{kg}$. propofol and relaxed with succinylcholine $1.5 \mathrm{mg} / \mathrm{kg}$ and ventilated with $\mathrm{O} 2+\mathrm{N} 2 \mathrm{O}$ for 3 minutes and then intubated with 7.5/8.0/8.5 size cuffed endotracheal tube and ETCO2 monitor was connected. Anesthesia was maintained with $\mathrm{O} 2$ and $\mathrm{N} 2 \mathrm{O}$ at 50:50\%. Either isoflurane or propofol infusion is used as maintenance anesthetics to maintain HR and BP nearproduction values. Inj. fentanyl supplemented as needed. Ventilation was controlled. Muscle paralysis was reversed at the end of surgery with $0.05 \mathrm{mg} . / \mathrm{kg}$. neostigmine and 0.01 $\mathrm{mg}$./kg glycopyrrolate Diclofenac sodium 75mg. Intramuscular (IM) was given before reversal of neuromuscular blockade for post-operation pain. Study drugs were injected Intravenous (IV) over 30 seconds.

Intraoperative $\mathrm{HR}, \mathrm{BP}, \mathrm{ETCO} 2$ were monitored every 5 minutes in the first hour and then every 15 minutes. ECG was monitored continuously for any change of rate and rhythm.

Duration of surgery and anesthesia was noted. The patient was observed for 24 hours postoperatively. Nausea, vomiting, and pain were recorded hourly for 4 hours and then atthe end of 24 hours. Discharge time from the recovery room was also noted. Any other complications were also noted. The number of episodes of emesis and nausea was recorded. Repeated vomiting within 1 minute was recorded as single emesis.

Nausea was measured using an 11 point visual numerical scale with

$0=$ No Nausea.

$10=$ Nausea as bad as can be.

A score of $>6=$ Severe

4 - 6 = moderate

$<4=$ minimal

Vomiting

$>2$ = Severe.

2 = Moderate.

$<2$ = Mild.

Rescue antiemetic consisted of $0.15 \mathrm{mg} . / \mathrm{kg}$. metoclopramide IV and was given for more than 2 episodes of vomiting. Epidural infusion with $0.125 \%$ was maintained postoperatively for 24 hours. The rescue analgesia consisted of $75 \mathrm{mg}$. diclofenac sodium IM was given when the pain was more than 5 in the scale. The discharge criterion from the recovery room to the ward was done based on the Modified Aldrete Scoring system. 


\section{Results}

In this study, a total of $n=160$ subjects were included out of which group | was $n=80$ and group II were $n=80$. The most common age group was $50-59$ years which had $n=45(28.1 \%)$ patients out of which group I was $n=24(15 \%)$ patients and $n=21(13.1 \%)$ patients. The next common age group was $20-$ 29 years out of which $n=23(14.4 \%)$ and $n=18(11.2 \%)$. The other details are given in table 1.

Table 1: Demographic profile of the patients involved in the study

\begin{tabular}{|c|c|c|c|c|c|}
\hline & & & $\begin{array}{c}\text { Group I } \\
\text { Dexamethasone }\end{array}$ & $\begin{array}{c}\text { Group II } \\
\text { Ondansetron }\end{array}$ & Total \\
\hline \multirow{8}{*}{ Age } & \multirow[t]{2}{*}{$20-29$ years } & Number & 23 & 18 & 41 \\
\hline & & Percentage & 14.4 & 11.2 & 25.6 \\
\hline & \multirow[t]{2}{*}{$30-39$ years } & Number & 16 & 20 & 36 \\
\hline & & Percentage & 10 & 12.5 & 22.5 \\
\hline & \multirow[t]{2}{*}{$40-49$ years } & Number & 17 & 21 & 38 \\
\hline & & Percentage & 10.6 & 13.1 & 23.8 \\
\hline & \multirow[t]{2}{*}{$50-59$ years } & Number & 24 & 21 & 45 \\
\hline & & Percentage & 15 & 13.1 & 28.1 \\
\hline \multirow{2}{*}{\multicolumn{2}{|c|}{ Total }} & Number & 80 & 80 & 160 \\
\hline & & Percentage & 50 & 50 & 100 \\
\hline
\end{tabular}

The sex-wise distribution of cases in this study showed in group I males was $n=32(20 \%)$ and females were $n=48(30 \%)$ out of total $n=160$. Similarly in group II males were $n=36(22.5 \%)$ and $\mathrm{n}=44(27.5 \%)$ shown in chart 1.

Chart 1: showing the sex-wise distribution of cases in the study

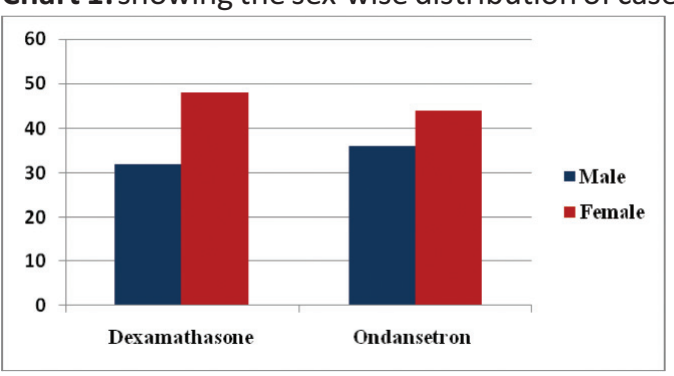

In this study out of $\mathrm{n}=160$ patients, the most common surgery was laparotomy with $n=39(24.4 \%)$ patients of which group I had $n=23(14.4 \%)$ and group II had $n=18(11.2 \%)$ patients. Renal surgeries were undertaken in Group I was $n=13(8.1 \%)$ of patients out of which Group II was $n=10(6.2 \%)$. Shoulder surgery was done $n=11(6.9 \%)$ in group I and $n=10(6.2 \%)$ in group II. Craniotomy was done in $n=8(5 \%)$ in group I and $\mathrm{n}=13(8.1 \%)$ in group II. The other details are as shown in table 2.

Table 2: Showing the type of surgery performed in both groups of study

\begin{tabular}{|l|l|c|c|c|}
\hline \multicolumn{1}{|c|}{ Type of Surgery } & \multicolumn{1}{c|}{ Count } & $\begin{array}{c}\text { Group I } \\
\text { Dexamethasone }\end{array}$ & $\begin{array}{c}\text { Group II } \\
\text { Ondansetron }\end{array}$ & Total \\
\hline \multirow{2}{*}{ Laparotomy } & Number & 23 & 18 & 39 \\
\cline { 2 - 5 } & Percentage & 14.4 & 11.2 & 24.4 \\
\hline \multirow{2}{*}{ Laparoscopic surgery } & Number & 16 & 8 & 18 \\
\cline { 2 - 5 } & Percentage & 10 & 5 & 11.2 \\
\hline \multirow{2}{*}{ Major Gynec Surgery } & Number & 17 & 8 & 16 \\
\cline { 2 - 5 } & Percentage & 10.6 & 5 & 10 \\
\hline
\end{tabular}


Ashwin et al

www. pimr.org.in

\begin{tabular}{|l|l|c|c|c|}
\hline \multirow{3}{*}{ Renal Surgery } & Number & 13 & 10 & 23 \\
\cline { 2 - 5 } & Percentage & 8.1 & 6.2 & 14.4 \\
\hline \multirow{3}{*}{ ENT Surgery } & Number & 9 & 13 & 22 \\
\cline { 2 - 5 } & Percentage & 5.6 & 8.1 & 13.8 \\
\hline \multirow{2}{*}{ Shoulder surgery } & Number & 11 & 10 & 21 \\
\cline { 2 - 5 } & Percentage & 6.9 & 6.2 & 13.1 \\
\hline \multirow{2}{*}{ Craniotomy } & Number & 8 & 13 & 21 \\
\cline { 2 - 5 } & Percentage & 5.0 & 8.1 & 13.1 \\
\hline \multirow{2}{*}{ Total } & Number & 80 & 80 & 160 \\
\cline { 2 - 5 } & Percentage & 50 & 50 & 100 \\
\hline
\end{tabular}

Nausea episodes were recorded from 0 - 4 hours showed $n=60$ (37.5\%) patients in group I was free of episodes and in group II $n=61(38 \%)$ were free of nausea. Severe nausea was seen in $\mathrm{n}=3$ in group I and $\mathrm{n}=2$ in group II respectively. The $\mathrm{p}$ values were not significant for all the grades in both the groups shown in table 3. The episodes of nausea recorded during the $4-24$ hours showed $n=58(36.2 \%)$ in group I and $n=60(37.5 \%)$ were without any episodes of nausea. The other details are shown in table 4.

Table 3: Incidences of Nausea from ( $0-4$ hours) in both the groups

\begin{tabular}{|c|c|c|c|c|c|}
\hline \multirow{9}{*}{$\begin{array}{l}\text { Nausea } \\
0-4 \text { hours }\end{array}$} & Grades & & $\begin{array}{c}\text { Group I } \\
\text { Dexamethasone }\end{array}$ & $\begin{array}{c}\text { Group II } \\
\text { Ondansetron }\end{array}$ & P values \\
\hline & \multirow{2}{*}{ Nil } & Number & 60 & 61 & \multirow{2}{*}{0.855} \\
\hline & & Percentage & 37.5 & 38.1 & \\
\hline & \multirow{2}{*}{ Mild } & Number & 10 & 11 & \multirow{2}{*}{0.998} \\
\hline & & Percentage & 6.2 & 6.9 & \\
\hline & \multirow{2}{*}{ Moderate } & Number & 7 & 6 & \multirow{2}{*}{0.814} \\
\hline & & Percentage & 4.4 & 3.8 & \\
\hline & \multirow{2}{*}{ Severe } & Number & 3 & 2 & \multirow{2}{*}{$>1.0$} \\
\hline & & Percentage & 1.9 & 1.2 & \\
\hline
\end{tabular}

Table 4: Incidences of Nausea from (4-24 hours) in both the groups

\begin{tabular}{|c|c|c|c|c|c|}
\hline \multirow{7}{*}{$\begin{array}{c}\text { Nausea } \\
\text { 4-24 hours }\end{array}$} & Grades & & $\begin{array}{c}\text { Group I } \\
\text { Dexamethasone }\end{array}$ & $\begin{array}{c}\text { Group II } \\
\text { Ondansetron }\end{array}$ & $P$ values \\
\hline & \multirow{2}{*}{ Nil } & Number & 58 & 60 & \multirow{2}{*}{0.556} \\
\hline & & Percentage & 36.2 & 37.5 & \\
\hline & \multirow{2}{*}{ Mild } & Number & 15 & 12 & \multirow{2}{*}{0.09} \\
\hline & & Percentage & 9.4 & 7.5 & \\
\hline & \multirow{2}{*}{ Moderate } & Number & 6 & 7 & \multirow{2}{*}{0.71} \\
\hline & & Percentage & 3.8 & 4.4 & \\
\hline
\end{tabular}




\begin{tabular}{|l|l|l|c|c|c|}
\hline \multirow{2}{*}{ Severe } & Number & 1 & 1 & \multirow{2}{*}{$>1.0$} \\
\cline { 3 - 5 } & & Percentage & 0.6 & 0.6 & \\
\hline
\end{tabular}

The records of vomiting grades from 0-4 hours showed that $\mathrm{n}=70$ patients in each group were free of vomiting episodes and in group I, mild episodes were found in $n=7(4.4 \%)$ moderate in $n=2(1.2 \%)$ severe episodes in $n=1(0.6 \%)$. For group II mild episodes were found in $n=8(5 \%)$ moderate in $n=1(0.6 \%)$ and severe in $n=1(0.6 \%)$. The $p$ values were not found to be significant.

Table 5: Incidences of Vomiting from (0-4 hours) in both the groups

\begin{tabular}{|c|c|c|c|c|c|}
\hline \multirow{9}{*}{$\begin{array}{l}\text { Vomiting } \\
0-4 \text { hours }\end{array}$} & Grades & & $\begin{array}{c}\text { Group I } \\
\text { Dexamethasone }\end{array}$ & $\begin{array}{c}\text { Group II } \\
\text { Ondansetron }\end{array}$ & $P$ values \\
\hline & \multirow{2}{*}{ Nil } & Number & 70 & 70 & \multirow{2}{*}{$>1.0$} \\
\hline & & Percentage & 43.8 & 43.8 & \\
\hline & \multirow{2}{*}{ Mild } & Number & 7 & 8 & \multirow{2}{*}{0.771} \\
\hline & & Percentage & 4.4 & 5.0 & \\
\hline & \multirow{2}{*}{ Moderate } & Number & 2 & 1 & \multirow{2}{*}{0.214} \\
\hline & & Percentage & 1.2 & 0.6 & \\
\hline & \multirow{2}{*}{ Severe } & Number & 1 & 1 & \multirow{2}{*}{0.369} \\
\hline & & Percentage & 0.6 & 0.6 & \\
\hline
\end{tabular}

Vomiting episodes recorded between 4 hours to 24 hours has shown that $n=71$ in group I and $n=74$ in group II were free of vomiting episodes. Mild episodes were recorded in $n=6$ patients of both the groups and moderate episodes in $n=3$ of group I sever episode in $n=1$ of group I. No moderate or severe episodes were recorded in group II patients shown in table 6.

Table 6: Incidences of Vomiting from (0-4 hours) in both the groups

\begin{tabular}{|c|c|c|c|c|c|}
\hline \multirow{9}{*}{$\begin{array}{l}\text { Vomiting } \\
\text { 4-24 hours }\end{array}$} & Grades & & $\begin{array}{c}\text { Group I } \\
\text { Dexamethasone }\end{array}$ & $\begin{array}{c}\text { Group II } \\
\text { Ondansetron }\end{array}$ & $P$ values \\
\hline & \multirow{2}{*}{ Nil } & Number & 71 & 74 & \multirow{2}{*}{0.992} \\
\hline & & Percentage & 44.4 & 46.2 & \\
\hline & \multirow{2}{*}{ Mild } & Number & 6 & 6 & \multirow{2}{*}{$>1.0$} \\
\hline & & Percentage & 3.8 & 3.8 & \\
\hline & \multirow{2}{*}{ Moderate } & Number & 3 & 0 & \multirow{2}{*}{0.114} \\
\hline & & Percentage & 1.9 & 0 & \\
\hline & \multirow{2}{*}{ Severe } & Number & 1 & 0 & \multirow{2}{*}{0.559} \\
\hline & & Percentage & 0.6 & 0 & \\
\hline
\end{tabular}

The post-operative requirement of opioids was recorded in both the group. In group I the requirement of opioids was in $\mathrm{n}=27$ cases and in group II it was required in $\mathrm{n}=23$ cases. However, the $p$ values not found to be significant. The side effects were seen in $n=2$ patients of group I had a mild headache. One patient in group II had flushing of face for which no treatment was needed none had diarrhea or constipation.

\section{Discussion}

The etiology of nausea and vomiting after high risk for PONV is not fully understood. Risk factors such as prolonged surgeries, long periods of $\mathrm{CO} 2$ insufflation, intra-operative use of isoflurane, female sex, $\mathrm{H}$ /o smoking, and intra-operative and post-operative use of opioids, intraoperative hypotension, and 
manipulation of abdominal viscera contribute to PONV [8] Different studies have been done to control PONV with various groups of drugs. In all these studies incidence of nausea has been very variable, probably related to different types of and durations of surgery. Previous studies have shown that compared to placebo, intravenous dexamethasone significantly reduced the rate and intensity of the PONV ${ }^{[9]}$. In the present study, we found $n=70$ patients in both the groups were free of vomiting episodes and in group I, mild episodes were found in $\mathrm{n}=7(4.4 \%)$ moderate in $\mathrm{n}=2(1.2 \%)$ severe episodes in $n=1(0.6 \%)$. For group II mild episodes were found in $n=8(5 \%)$ moderate in $n=1(0.6 \%)$ and severe in $n=1(0.6 \%)$. Erhan et al; conducted a comparative study on ondansetron (4 mg IV), granisetron (3 mg IV) and dexamethasone ( $8 \mathrm{mg}$ IV) effects given before induction of anesthesia to prevent postoperative PONV in laparoscopic cholecystectomy. They showed that compared to placebo all three drugs in a similar manner significantly reduced the incidence rate of PONV ${ }^{[10]}$. Gupta A [11] also concluded that intravenous dexamethasone and ondansetron had a similar effect on PONV prevention. The results of this study are in agreement with the findings of Gupta $A^{[11]}$. Munoz et al; ${ }^{[12]}$ showed that the effects of dexamethasone and ondansetron in preventing PONV were similar. Schnaider TB et al; ${ }^{[13]}$ showed that ondansetron was better than dexamethasone. Another study showed that dexamethasone was a little more effective than ondansetron in preventing posttonsillectomy PONV. Corticosteroids interact with specific receptor proteins in target tissues to regulate the expression of corticosteroid-responsive genes thereby changing the levels and array of proteins synthesized by the various target tissues. As a consequence of the time required for the changes in gene expression and protein synthesis, most of the effect of corticosteroids is not immediate ${ }^{[14]}$. Dexamethasone, administered at a prophylactic dose of 8-10 mg IV, effectively prevents nausea and vomiting with an NNT of approximately $4(44 \%)$ more recently, smaller doses $(2.5-5 \mathrm{mg})$ are as effective [15]

Dexamethasone appears to be most effective when administered before the induction of anesthesia rather than at the end. Side effects with long-term administration of corticosteroids can include wound infection and adrenal suppression, among others, but adverse events have not been noted after a single bolus dose of dexamethasone. In our study, in the ondansetron group, early nausea is mild in $6.9 \%$, moderate in $3.8 \%$, and severe in $1.2 \%$ of patients. Whereas in the dexamethasone group early nausea is mild in $6.2 \%$, moderate in $4.4 \%$, severe in $1.9 \%$ of patients. In the ondansetron group, late nausea is mild in $9.4 \%$, moderate in $3.8 \%$, and severe in $0.6 \%$ of patients. Whereas in the dexamethasone group late nausea is mild in $7.5 \%$, moderate in $4.4 \%$, severe in $0.6 \%$ of patients. In the ondansetron group, early vomiting is mild in $5.0 \%$, moderate in $0.6 \%$, and severe in $0.6 \%$ of patients. Whereas in the dexamethasone group early vomiting is mild in $4.4 \%$, moderate in $1.2 \%$, severe in $0.6 \%$ of patients. In the ondansetron group, late vomiting is mild in $3.8 \%$, moderate and severe in none of the patients. Whereas in the dexamethasone group early vomiting is mild in $3.8 \%$, moderate in $1.9 \%$, severe in none of the patients. post operative pain scores were comparable in both groups. Rescue analgesia requirement was also not statistically different between the groups. As dexamethasone has potent antiinflammatory ${ }^{[16,17]}$ effects, it may be beneficial for postoperative pain. However, in our study potent opioid (fentanyl) was administered as premedication and also during the intraoperative period. Therefore, the influence of dexamethasone on postoperative pain may have been masked. Sixteen patients (20\%) in group O required rescue anti-emetics compared to twenty patients $(25 \%)$ in group $D$. The difference was not significant. Adverse effects related to a single dose of dexamethasone are extremely rare. Less than 24 hours of dexamethasone therapy is considered safe and almost without adverse effects ${ }^{[5,18-20]}$. In our study complication due to steroid was not significant. Last but not least, the cost is an everincreasing concern in today's health care system. Dexamethasone is a relatively inexpensive drug compared to other anti-emetics ${ }^{[21,22]}$

\section{Conclusion}

We conclude that dexamethasone given intravenously just after intubation and ondansetron given intravenously just before extubation are safe and have similar efficacy in postoperative nausea and vomiting after elective surgeries under general anesthesia having a high risk of PONV.

\section{REFERENCES}

1. Saeeda Islam, P.N. Jain, Postoperative nausea and vomiting (PONV): A review article. Indian J. Anaesth 2004, 48(4): 253-58.

2. Odom-Forren J, Jalota L, Moser DK, Lennie TA, Hall LA, Holtman J, Hooper V, Apfel CC. Incidence and predictors of post-discharge nausea and vomiting in a 7-day population.JClinAnesth. 2013; S0952-8180(13)00223-27.

3. Apfel CC, Heidrich FM, Jukar-Rao S, Jalota L, Hornuss C, Whelan RP, Zhang K, Cakmakkaya OS. Evidence-based analysis of risk factors for postoperative nausea and vomiting.Br J Anaesth. 2012 Nov;109 (5):742-53.

4. Keyes M. Management of postoperative nausea and vomiting in ambulatory surgery: the big little problem. Clin Plast Surg. 2013 Jul;40(3):447-52.

5. M. Elhakim, Naglaa M Ali, Inas Rashed, Mostafa K. Riad, Mona Refat, Dexamethasone reduces postoperative vomiting and pain after pediatric tonsillectomy. Can. J. Anesth 2003; 50(4) : 392-97 
6. Daniel E. Becker. Nausea, Vomiting, and Hiccups: A Review of Mechanisms and Treatment. Anesth Prog 2010; 57(4): 150-57.

7. Tina K. Machu. Therapeutics of 5-HT3 Receptor Antagonists: Current Uses and Future Directions Pharmacol Ther. 2011; 130(3):338-47.

8. Safiya IS, D. Nagare Khan, G Hegade, M Marutheesh. Postoperative nausea and vomiting: A simple yet complex problem. Anesth Essay Res 2016; 10(3):388-96.

9. K. Korttila. The study of postoperative nausea and vomiting. Br. J. Anaesth 1992; 6.9(S): 20-23.

10. Alain Borgeat, Georgios Ekatodramis, Carlo A. Schenker, Postoperative nausea and vomiting in regional anesthesia. Anesthesiology 2003; 98: 530- 47.

11. Gupta A. Evidence-based medicine in day surgery. Curr Opin Anaesthesiol 2007;20:520-25.

12. Sweis I, Yegiyants SS, Cohen MN. The management of postoperative nausea and vomiting: current thoughts and protocols. Aesthetic Plast Surg. 2013; 37(3):625-33.

13. Schnaider TB, Vieira AM, Brandão AC. Comparative study of anti-emetics and their association, in the prevention of postoperative nausea and vomiting in patients undergoing gynecologic surgeries. Rev Bras Anestesiol. 2008; 58:614-22.

14. Mokhtar Elhakim, Naglaa M. Dexamethasone reduces postoperative vomiting and pain after pediatric tonsillectomy Can J Anaesth 2003; 50:4;392-97.

15. Liu K, Hsu CC, Chia YY: The effect of dose of dexamethasone for antiemesis after major gynecological surgery. Anesth Analg1999; 89:1316-18.

16. Goodman and Gilman's, The pharmacological basis of therapeutics 2010; 12th edition 249-262, 1459-86.

17. Colin Dollery. Therapeutic Drug Vol I, 2nd edition, Churchill Living stone 1999; O21-024.

18. Tripathi KD. Essentials of Medical Pharmacology, New Delhi, Jaypee Brothers Medical Publishers (P) Ltd. 2003; 261.

19. Visser K, Hassink EA, Bonsel GJ, et al: Randomized controlled trial of total intravenous anesthesia with propofol versus inhalation anesthesia with isoflurane nitrous oxide: Postoperative nausea with vomiting and economic analysis. Anesthesiology 2001; 95:616-26.
20. Wang JJ, Ho ST, Tzeng JI, Tang CS: The effect of timing of dexamethasone administration on its efficacy as a prophylactic antiemetic for postoperative nausea and vomiting. Anesth Analg 2000; 91:136-39.

21. Gan T, Sloan F, Dear G, et al: How much are patients willing to pay to avoid postoperative nausea and vomiting? Anesth Analg 92:393-400, 2001.

22. Watcha MF: The cost-effective management of postoperative nausea and vomiting. Anesthesiology 2000; 92:931-33.

How to cite this article : Joginipally A, Mudgalkar N.A Comparative Study of Single Dose Dexamethasone versus Ondansetron for control of Post Operative Nausea and Vomiting after High-Risk Surgeries. Perspectives in Medical Research 2020; 8(1):64-70

Sources of Support: Nil,Conflict of interest:None declared. 